\title{
A novel PRNP-G131R variant associated with familial prion disease
}

Jumana T. Alshaikh, MD, Kefeng Qin, PhD, Lili Zhao, MS, and James A. Mastrianni, MD, PhD

Neurol Genet 2020;6:e454. doi:10.1212/NXG.0000000000000454

\author{
Correspondence \\ Dr. Mastrianni \\ jmastria@uchicago.edu
}

Roughly 40 autosomal dominant mutations of the prion protein gene (PRNP) cosegregate with familial Creutzfeldt-Jakob disease (CJD), fatal familial insomnia, or Gerstmann-SträusslerScheinker disease (GSS) ${ }^{1,2}$ Genetic prion disease in African Americans is rarely reported. We sequenced the PRNP coding segment of a 43-year-old African American woman with rapidly progressive dementia and a positive family history of early onset dementia not previously recognized as genetic prion disease.

\section{Case report}

A 43-year-old woman previously unknown to the University of Chicago was transferred for evaluation of possible stroke causing a fall and altered mental status. Nine months earlier, she developed mild dizziness/vertigo/disequilibrium that was managed with meclizine. Three months before admission, the patient stopped working because of cognitive problems; the family reported that she had been repeating herself, misplacing items, and having word-finding difficulties for a year. She was referred for a cognitive assessment but never followed up. Her family history was remarkable for a mother and sister with a 4-5-year course of dementia and progressive gait dysfunction beginning in their 30 s and 40 s (figure, A).

On examination, she was alert with intermittent eye contact and oriented only to self. She was unable to name her daughter and believed she was in a school. Speech was nonfluent, agrammatical, with minimal content, and interrupted by frequent bouts of inappropriate laughter. She was bradyphrenic and only able to follow simple commands intermittently. Cranial nerves were generally intact, although assessment of ocular dysmetria and nystagmus was limited by poor attention. Strength was grossly intact, and tendon reflexes were $3+$ in the upper limbs, $2+$ in the lower limbs, and there was bilateral nonsustained ankle clonus with flexor plantar responses. Gait was wide-based with a short stride and moderate truncal ataxia that required one-person assist.

Serum laboratory testing was extensive and unremarkable, including complete blood count, comprehensive metabolic panel, thyroid stimulating hormone, vitamins B1, B12, E, and A, folate, ammonia, HIV, reactive plasma reagin, anti-nuclear antibody, anti-SSA antibody, antiSSB antibody, anti-RNP antibody, anti-Smith antibody, angiotensin converting enzyme, antithyroglobulin and anti-thyroperoxidase antibodies, and a complete paraneoplastic panel, including anti-NMDA and anti-GAD65 antibodies. CSF analysis was negative for infectious or inflammatory process (white blood cell count 0 , red blood cell count 16 , protein 25 , glucose 62 , negative viral and bacterial encephalitis panel, negative oligoclonal bands, and angiotensin converting enzyme). A second lumbar puncture was performed to test for CJD biomarkers, although 14-3-3 and real time quaking induced conversion assays were reported as "inconclusive" because of blood contamination from a difficult lumbar puncture. However, T-Tau was significantly elevated at 3,026 pg/ML (values $>1,150 \mathrm{pg} / \mathrm{mL}$ support prion disease).

From the Department of Neurology (J.T.A., K.Q., L.Z., J.A.M.), University of Chicago, IL; and Department of Neurology (J.T.A.), Johns Hopkins University, Baltimore, MD.

Dr. Alshaikh is now with the University of Chicago.

Go to Neurology.org/NG for full disclosures. Funding information is provided at the end of the article.

The Article Processing Charge was funded by Brain Research Foundation.

This is an open access article distributed under the terms of the Creative Commons Attribution-NonCommercial-NoDerivatives License 4.0 (CC BY-NC-ND), which permits downloading and sharing the work provided it is properly cited. The work cannot be changed in any way or used commercially without permission from the journal. 


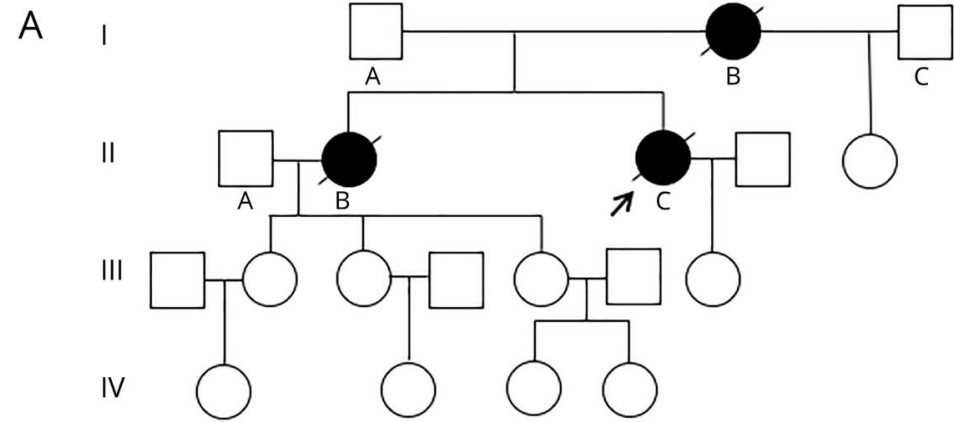

B
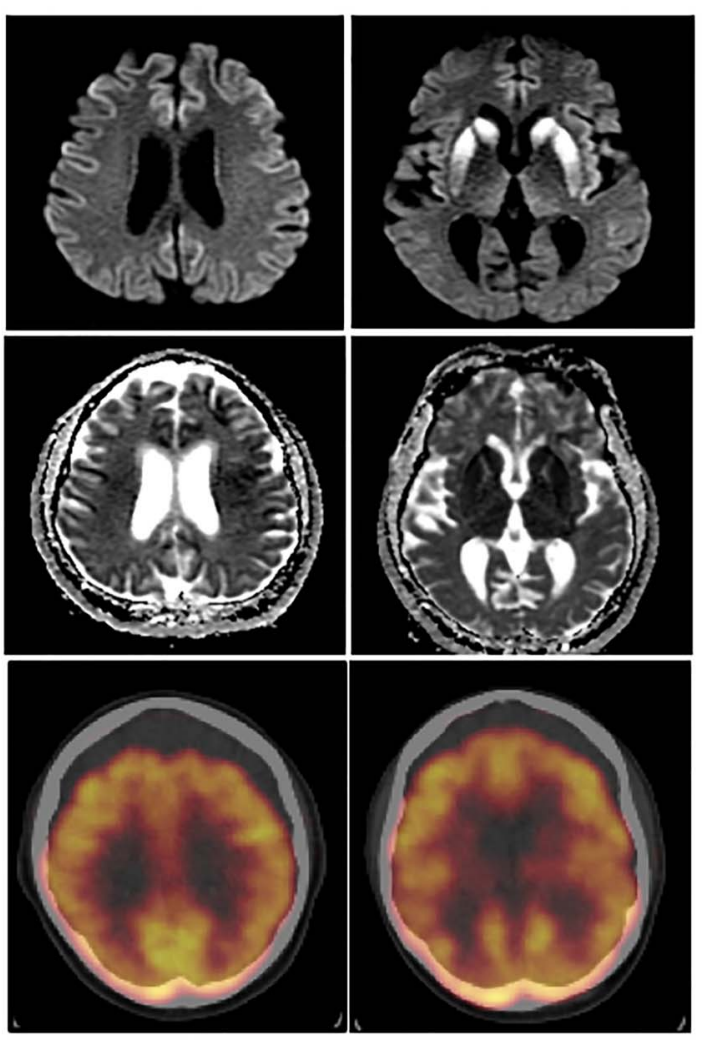

C
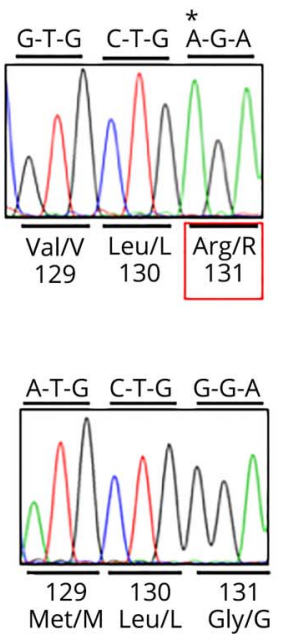

(A) Pedigree of the family. The proband (arrow) had one child who was less than 30 years of age and did not wish to have genetic testing. The proband's mother (I.B) and sister (II.B) developed a progressive dementia followed by gait ataxia in a similar manner as the proband, but at a somewhat slower pace. I.B. was in her late 30 s at disease onset and was given a clinical diagnosis of Alzheimer disease. II.B. was in her early 40s and was clinically diagnosed with dementia with Lewy bodies. No other information was available, and no records were provided. Both died within 4-5 years of symptom onset. No other known affected members were reported. (B) MRI (DWI) sequences (top row) with corresponding ADC images (middle row) and comparable brain sections of FDG-PET (bottom row) of the proband. Signal hyperintensity (restricted diffusion) of DWI sequences is especially prominent within the bilateral basal ganglia but is also diffusely present throughout the cortical ribbon (left), especially within frontal and superior parietal cortices. Corresponding ADC images show diffuse cortical hypointense signals that overlap with regions of DWI hyperintensity, supporting restricted diffusion in most cortical regions, although posterior temporal lobes appear relatively spared. Comparable sections of the FDG-PET scan (bottom row) show hypometabolism in cortical regions and basal ganglia that generally parallel the regional hyperintensities of the cortex and basal ganglia. The posterior cingulate cortex is relatively spared. (C) Chromatograms of cloned alleles of variant (top) and normal (bottom) PRNP sequences showing a $G$ to $A$ transition at the first nucleotide of codon 131, which results in an arginine (R) substitution of the normal glycine $(G)$. The variant is allelic with valine $(\mathrm{V})$ on the polymorphic codon 129, whereas the normal allele encodes methionine (M). A single octapeptide repeat deletion (not shown), a known nonpathogenic polymorphism, was also present on the normal allele. Sequencing was performed as previously described. ${ }^{7} \mathrm{ADC}=$ apparent diffusion coefficient; DWI = diffusion weighted imaging; FDG-PET = fluorodeoxyglucose positron emission tomography.
EEG was slow $(6-7 \mathrm{~Hz})$ and without periodic sharp wave complexes. MRI diffusion-weighted imaging (DWI) revealed restricted diffusion within the bilateral basal ganglia and in a "cortical ribboning" pattern throughout multiple cortical regions, consistent with CJD (figure, B). An fluorodeoxyglucose positron emission tomography scan displayed generalized cortical and bilateral basal ganglia hypometabolism (figure, B). A full body CT with contrast was negative for tumor.

She was eventually discharged to hospice and died within 16 months of symptom onset. The family declined an autopsy.

PRNP sequencing revealed a novel single nucleotide change (c.391G>A), resulting in an arginine (R) substitution of glycine $(\mathrm{G})$ at residue 131 paired with valine $(\mathrm{V})$ coding at the polymorphic codon $129(129 \mathrm{~V})$. The normal allele carried a single octapeptide repeat deletion, a known polymorphism, with methionine (M) at codon 129 (figure, C).

\section{Discussion}

Although found in a single patient, the early onset of disease in the proband and family members strongly supports the PRNPG131R/129V variant as the cause of prion disease in this African American family. Assessment of this variant using the PolyPhen-2 molecular modeling software ${ }^{3}$ also supports a pathogenic effect (probability of $0.89-1.0$ ). Of interest, a valine (V) substitution at 
this same position, although allelic with methionine at residue 129 (PRNP-G131V/129M), ${ }^{4,5}$ was previously described in 2 families that displayed dementia preceding ataxia over a 5-15-year course. The brain histopathologic findings in those cases displayed prion protein $(\mathrm{PrP})$ amyloid plaque deposition that classifies the PRNPG131V/129M variant as GSS. ${ }^{4,5}$ Although our case lacks histopathologic classification, the rapid course and pronounced restricted diffusion on MRI, a feature that generally correlates with the underlying spongiform degeneration, support CJD as the disease subtype. However, the clinical phenotype of GSS can be quite variable and although DWI imaging is typically negative in GSS, rare cases report a positive MRI. ${ }^{6}$ DWI imaging associated with the PRNP-G131V/129M variant was not reported, leaving that question open. Thus, the question of whether the PRNP-G131R/ $129 \mathrm{~V}$ variant predisposes $\mathrm{PrP}$ to misfold into a CJD-determining conformation rather than the GSS conformation induced by PRNP-G131V/129M will remain unanswered until the availability of direct histologic evidence.

\section{Study funding}

Brain Research Foundation, Chicago, IL.

\section{Disclosure}

J.T. Alshaikh, K. Qin, L. Zhao, and J.A. Mastrianni report no disclosures. Go to Neurology.org/NG for full disclosures.

\section{Publication history}

Received by Neurology: Genetics December 15, 2019. Accepted in final form May 11, 2020.

\section{Appendix Authors}

\begin{tabular}{lll}
\hline $\begin{array}{l}\text { Author } \\
\text { Name }\end{array}$ & Location & Contributions \\
\hline $\begin{array}{l}\text { Jumana T. } \\
\text { Alshaikh, MD }\end{array}$ & $\begin{array}{l}\text { Department of } \\
\text { Neurology, } \\
\text { University of Chicago }\end{array}$ & $\begin{array}{l}\text { Acquisition of clinical data, } \\
\text { interpretation of data, and } \\
\text { drafting and revising the } \\
\text { manuscript }\end{array}$ \\
\hline $\begin{array}{l}\text { Kefeng Qin, } \\
\text { PhD }\end{array}$ & $\begin{array}{l}\text { Department of } \\
\text { Neurology, } \\
\text { University of Chicago }\end{array}$ & $\begin{array}{l}\text { Genetic sequence analysis and } \\
\text { cloning and drafting and } \\
\text { revising the manuscript }\end{array}$ \\
\hline $\begin{array}{l}\text { Lili Zhao, MS } \\
\text { Department of } \\
\text { Neurology, } \\
\text { University of Chicago }\end{array}$ & $\begin{array}{l}\text { DNA extraction, genetic } \\
\text { sequencing, and cloning }\end{array}$ \\
\hline $\begin{array}{l}\text { James A. } \\
\text { Mastrianni, }\end{array}$ & $\begin{array}{l}\text { Department of } \\
\text { Neurology, }\end{array}$ & $\begin{array}{l}\text { Coordination of project, } \\
\text { acquisition and interpretation } \\
\text { of data, and drafting and } \\
\text { revising the manuscript }\end{array}$ \\
\hline
\end{tabular}

\section{References}

1. Schmitz M, Dittmar K, Llorens F, et al. Hereditary human prion diseases: an update. Mol Neurobiol 2017;54:4138-4149.

2. Mastrianni JA. The genetics of prion diseases. Genet Med 2010;12:187-195.

3. Adzhubei IA, Schmidt S, Peshkin L, et al. A method and server for predicting damaging missense mutations. Nat Methods 2010;7:248-249.

4. Panegyres PK, Toufexis K, Kakulas BA, et al. A new PRNP mutation (G131V) associated with Gerstmann-Sträussler-Scheinker disease. Arch Neurol 2001;58: 1899-1902.

5. Jansen C, Parchi P, Capellari S, et al. A second case of Gerstmann-SträusslerScheinker disease linked to the G131V mutation in the prion protein gene in a Dutch patient. J Neuropathol Exp Neurol 2011;70:698-702.

6. Wang J, Xiao K, Zhou W, Shi Q, Dong XP. Analysis of 12 Chinese patients with proline-to-leucine mutation at codon 102-associated Gerstmann-Sträussler-Scheinker disease. J Clin Neurol 2019;15:184-190.

7. Cali I, Mikhail F, Qin K, et al. Impaired transmissibility of atypical prions from genetic CJD. Neurol Genet 2018;4:e253. 


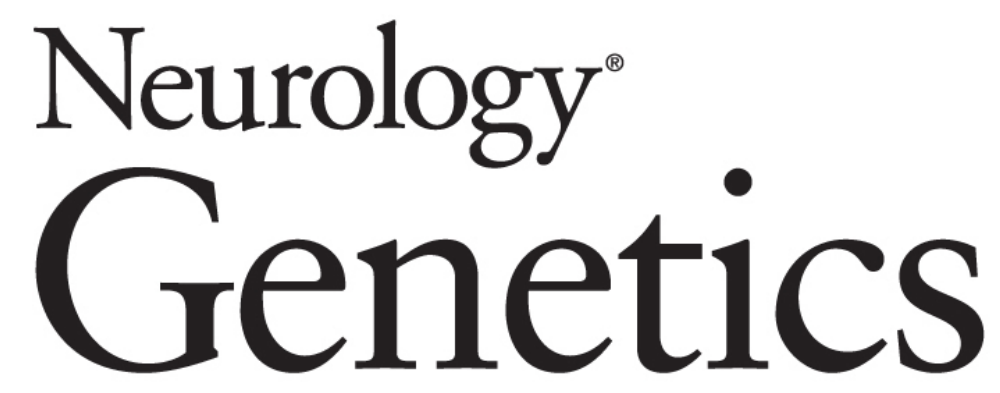

A novel PRNP-G131R variant associated with familial prion disease

Jumana T. Alshaikh, Kefeng Qin, Lili Zhao, et al.

Neurol Genet 2020;6;

DOI 10.1212/NXG.0000000000000454

This information is current as of June 5, 2020

\section{Updated Information \&} Services

\section{References}

Subspecialty Collections

Permissions \& Licensing

\section{Reprints}

including high resolution figures, can be found at: http://ng.neurology.org/content/6/4/e454.full.html

This article cites 7 articles, 1 of which you can access for free at: http://ng.neurology.org/content/6/4/e454.full.html\#\#ref-list-1

This article, along with others on similar topics, appears in the following collection(s):

All Clinical Neurology

http://ng.neurology.org//cgi/collection/all_clinical_neurology All Genetics

http://ng.neurology.org//cgi/collection/all_genetics

Prion disease; see Infections/prion

http://ng.neurology.org//cgi/collection/prion_disease

Information about reproducing this article in parts (figures,tables) or in its entirety can be found online at:

http://ng.neurology.org/misc/about.xhtml\#permissions

Information about ordering reprints can be found online:

http://ng.neurology.org/misc/addir.xhtml\#reprintsus

Neurol Genet is an official journal of the American Academy of Neurology. Published since April 2015, it is an open-access, online-only, continuous publication journal. Copyright Copyright @ 2020 The Author(s). Published by Wolters Kluwer Health, Inc. on behalf of the American Academy of Neurology.. All rights reserved. Online ISSN: 2376-7839.

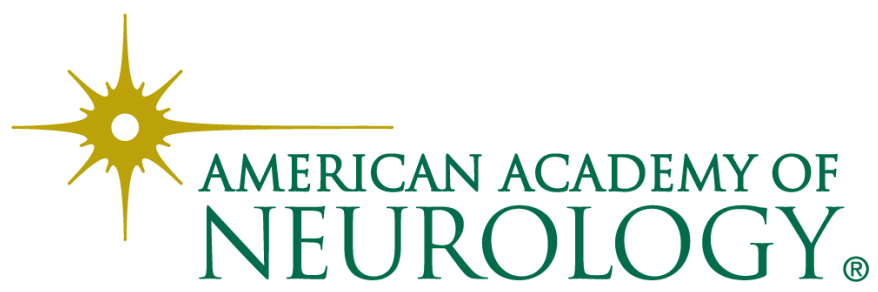

